\title{
Synthesis of p-Phosphonomethyl-L-phenylalanine using Camphor Sultam or D-Valine as Chiral Auxiliaries and its Incorporation into Integrin Sequences
}

\author{
Elisabeth Larsson and Björn Lüning
}

Department of Organic Chemistry, Arrhenius Laboratories, Stockhoim University, S-10691 Stockholm, Sweden

\begin{abstract}
Larsson, E. and Lüning, B., 1996. Synthesis of $p$-Phosphonomethyl-L-phenylalanine using Camphor Sultam or D-Valine as Chiral Auxiliaries and its Incorporation into Integrin Sequences. - Acta Chem. Scand. 50: 54-57 () Acta Chemica Scandinavica 1996.

The synthesis of $N$-Boc-p-phosphonomethyl-L-phenylalanine with two different chiral auxiliaries, camphor sultam or D-valine is described. The preparations have essentially identical properties and have been used to incorporate the amino acid into two integrin peptides as non-hydrolyzable isosteres of phosphotyrosine.
\end{abstract}

One of the more prominent signal pathways in cellular transmembrane signalling involves the phosphorylation of a tyrosine in the cytoplasmic portion of a receptor protein. This is a well known path for a series of insulin and insulin-like receptors. For other receptors, e.g., the integrins, documentation of phosphorylation by tyrosine kinases is still rather scarce. Most, although not all, $\beta$-chains of the integrins contain a tyrosine in a position that may allow for phosphorylation to be a potential pathway for the integrins as well. In order to study the phosphorylation in more detail we have synthesized portions of the cytoplasmic domains of the $\beta_{1}$ and the $\beta_{3}$ chains of integrins (KWDTGENPIYKSAVTT and KWDTANNPLYKEATST) using phosphorylated tyrosine in the synthesis. ${ }^{1}$ Antibodies raised against those peptides specifically labelled the podosomes of Rous sarcoma virustransformed fibroblasts but did not stain non-transformed fibroblasts. ${ }^{1}$ Antibodies were, however, formed with great difficulty due to extensive dephosphorylation in vivo. We have therefore chosen to synthesize the corresponding peptides using $p$-phosphonomethyl-L-phenylalanine in place of phosphorylated tyrosine.

\section{Results and discussion}

At the onset of this work two methods using racemic p-phosphonomethyl-DL-phenylalanine were known. ${ }^{2,3}$ After incorporation into peptide synthesis the diastereomeric peptides were separated. The synthesis of the L-form of $p$-phosphonomethyl phenylalanine using the Schöllkopf method ${ }^{4}$ has been presented in a short version by Cushman. ${ }^{5}$ During a reinvestigation of his data we felt that a further route to this versatile amino acid was de- sirable. In this paper we present the synthesis of p-phosphonomethyl-L-phenylalanine by the Oppolzer method $^{6}$ using camphor sultam as the chiral auxiliary. Preparations of Boc-p-dimethylphosphonomethyl-Lphenylalanine obtained by the two methods appear to be identical and they were then used in the synthesis of peptides matching the cytoplasmic tail of $\beta_{1}$ and $\beta_{3}$ integrin chains.

Synthesis according to the Schöllkopf method along the lines proposed by Cushman ${ }^{5}$ invariably led to incomplete reaction between the bromo compound and the lithiated Schöllkopf reagent. Any such difficulty was not observed in the reaction between the same bromo compound and the lithiated sultam glycinate used in the Oppolzer method. ${ }^{6}$ To remove excess unchanged bromo compound the reaction mixture was further reacted with pyridine prior to purification. Another by-product that appears after reaction with the Schöllkopf reagent has a molecular weight two mass units lower than the desired compound. This can only be explained as being the aromatic pyrazine analogue obtained by hydride transfer. This by-product is not easily separated from the desired material, but does not undergo cleavage to amino acid methyl esters and can therefore be removed in the subsequent step.

In the Oppolzer method the dithiocarbamate group is usually removed first with dilute acid and then the chiral auxiliary camphor sultam with lithium hydroxide. Using this sequence of events we found that the methyl phosphonate groups were also partially saponified. Using the reverse order of treatments, lithium hydroxide first and then dilute acid, reduced the loss of methyl groups from the phosphonate to a great extent. The enantiomeric purity was deduced from the optical rotation that was simi- 
lar in preparations from the two methods and corresponded with the latest recorded value in the literature. ${ }^{7}$

Since there is a difference between the $\mathrm{p} K_{\mathrm{a} 2}$ of tyrosine phosphate and p-phosphonomethyl-L-phenylalanine, antibodies raised to peptides containing the latter will not necessarily always recognize the corresponding peptides containing the former. For this reason it is essential to use the 'natural' phosphorylated peptides when screening for any antibodies formed. Earlier methods for the production of phosphorylated peptides used by us involved the synthesis using the Fmoc technique with benzyl protection of the phosphate group. ${ }^{1}$ This method has the disadvantage that the benzyl phosphate is sensitive to strong bases and nucleophiles, precluding the use of piperidine to remove the Fmoc group. The use of morpholine to remove the Fmoc group, however, may result in incomplete deprotection. For this reason we present here the synthesis of tyrosine phosphorylated $\beta_{1}$ and $\beta_{3}$ intracellular chains by means of the Boc technique and with allyl ester protection of the phosphate group. The latter can be removed with $\operatorname{Pd}(0)^{8}$ orthogonally to the other protective groups used in Boc mediated synthesis.

\section{Experimental}

Materials. tert-Butoxycarbonyl (Boc)-protected amino acids were purchased from Bachem Feinchemikalien, Switzerland. 1,3-Diisopropylcarbodiimide (DIPCDI), 1-hydroxybenzotriazole (HOBT), dimethyl sulfide, di-tertbutyl dicarbonate $\left(\mathrm{Boc}_{2} \mathrm{O}\right)$ and trifluoroacetic acid were from Fluka, $m$-cresol, trifluoromethanesulfonic acid, butyllithium $(1.6 \mathrm{M})$ in hexane and $(2 R)-(-)-2,5$-dihydro3,6-dimethoxy-2-isopropylpyrazine (Schöllkopf reagent) were from Merck, anisole was from Aldrich. $N$-[Bis(methylsulfanyl)methylene]glycine-(2R)-camphor sultam was purchased from Oxford Asymmetry. Dichloromethane (DCM) was run through an alumina column and then dried over $4 \AA$ molecular sieves, $N, N$-dimethylformamide (DMF) was dried over $4 \AA$ molecular sieves, $N, N$ diisopropylethylamine (DIPEA) was distilled successively over $\mathrm{KOH}$ and ninhydrin.

Fast atom bombardment mass spectrometry (FAB-MS) and nuclear magnetic resonance (NMR). FAB-MS spectra were recorded on a JEOL SX102 double focussing mass spectrometer with a FAB ion source and JMA DA6000 data system. The peptides were dissolved in $30 \%$ aqueous acetic acid and evaporated on the FAB-target, after which a mixture of $70 \%$ aqueous formic acid and glycerol (1:1) as a matrix was added, and the sample was bombarded with $10 \mathrm{keV}$ xenon atoms. Spectra of positive ions were recorded in the range $\mathrm{m} / \mathrm{z} 50-2550$ with a resolution of 3000 .

Carbon $\left({ }^{13} \mathrm{C}\right)$, proton $\left({ }^{1} \mathrm{H}\right)$ and phosphorus $\left({ }^{31} \mathrm{P}\right)$ NMR spectra were recorded on a JEOL GSX 270 spectrometer. Chemical shifts are given in parts per million (ppm) relative to tetramethylsilane (TMS $\delta_{c}=0.00$ ) in $\mathrm{C}^{2} \mathrm{HCl}_{3}$
$\left(\mathrm{CDCl}_{3}\right)$, 3-trimethylsilylpropionic acid $\left(\mathrm{TSP} \delta_{\mathrm{H}}=0.00\right)$ in ${ }^{2} \mathrm{H}_{2} \mathrm{O}$ and $85 \% \mathrm{H}_{3} \mathrm{PO}_{4}\left(\delta_{\mathrm{p}}=0.00\right)$ for ${ }^{31} \mathrm{P}$.

Gel permeation chromatography was performed in an FPLC system using a column of Superdex 30 (Pharmacia $\mathrm{AB}$ ), using aqueous $0.07 \mathrm{M}$ pyridinium acetate buffer $(\mathrm{pH}$ 5.4) as the eluant, and was monitored with a differential refractometer.

WARNING: Hexamethylphosphoric triamide (HMPA) is highly carcinogenic and its use is restricted by law in most countries. In this country it can be used only in specially equipped laboratories under a licence.

Synthesis of (2R, 2' $\mathrm{S})-\mathrm{N}-\{\mathrm{N}-$ /bis(methylsulfanyl)methylene]-p-dimethylphosphonomethylphenylalanyl $\}$ bornane-10,2sultam 1. To a stirred solution of $N$-[bis(methylsulfanyl)methylene ]glycine-( $2 R)$-camphorsultam $(0.474 \mathrm{~g}$, $1.25 \mathrm{mmol})$ in THF $(10 \mathrm{ml})$ at $-78^{\circ} \mathrm{C}$ was added butyllithium (1.6 $\mathrm{M}$ in hexane; $1.0 \mathrm{ml}, 1.6 \mathrm{mmol}$ ) dropwise under rigorous temperature control, followed after $1 \mathrm{~h}$, by $\alpha$-bromo- $\alpha^{\prime}$-dimethylphosphono- $p$-xylene ${ }^{5}$ (1 g, $3.41 \mathrm{mmol})$ and tetrabutylammonium iodide $(0.28 \mathrm{~g}$, 0.1 equiv.) dissolved in THF $(2 \mathrm{ml})$ and hexamethylphosphoric triamide (HMPA) (1.6 ml). The mixture was stirred at $-78^{\circ} \mathrm{C}$ for $5 \mathrm{~h}$ and was then permitted to reach room temperature over a period of $10 \mathrm{~h}$, upon which the reaction was quenched with brine $(4 \mathrm{ml})$. The aqueous phase was extracted three times with ethyl acetate and the combined organic phases washed with brine and dried with magnesium sulfate. After evaporation, the reaction mixture was treated with pyridine for $2 \mathrm{~h}$ at $0^{\circ} \mathrm{C}$ to remove the excess of bromo compound. Diethyl ether and water were added, the aqueous phase was extracted three times with diethyl ether and dried with magnesium sulfate. After evaporation with toluene, the product was purified by column chromatography on silica eluted initially with chloroform, then with chloroform-methanol (80:1) to give 1 as an oil $(0.62 \mathrm{~g}, 84 \%) .{ }^{1} \mathrm{H}$ NMR $\left(270 \mathrm{MHz}, \mathrm{CDCl}_{3}\right): \delta 0.94,0.97$ (bridge $\left.\mathrm{CH}_{3}\right), 2.40,2.44$ $\left(\mathrm{S}-\mathrm{CH}_{3}\right), 3.12\left(\mathrm{Ar}-\mathrm{CH}_{2}-\mathrm{P}, J_{\mathrm{PCH}}=21.6 \mathrm{~Hz}\right), 3.62,3.66(\mathrm{P}-$ $\left.\mathrm{OCH}_{3}\right),{ }^{31} \mathrm{P}$ NMR $\left(109.4 \mathrm{MHz}, \mathrm{CDCl}_{3}\right): \delta+28.9$.

Boc-p-dimethylphosphonomethyl-L-phenylalanine 2. To a stirred solution of $1(0.402 \mathrm{~g}, 0.683 \mathrm{mmol})$ in THF $(5.5 \mathrm{ml})$, was added $1 \mathrm{M} \mathrm{LiOH}(1.4 \mathrm{ml})$. After $4 \mathrm{~h}$ at room temperature the reaction mixture was neutralized with $1 \mathrm{M} \mathrm{HCl}$ and evaporated to dryness. The residue was dissolved in THF $(9.7 \mathrm{ml})$ and $1 \mathrm{M} \mathrm{HCl}(9.7 \mathrm{ml})$ was added. The mixture was stirred for $4 \mathrm{~h}$ and then extracted three times with diethyl ether. The aqueous phase was evaporated completely. Without further purification the crude amino acid hydrochloride was dissolved in water $(15 \mathrm{ml})$ and dioxane $(30 \mathrm{ml})$ and the $\mathrm{pH}$ was adjusted to 9 with sodium carbonate. The mixture was cooled to $0^{\circ} \mathrm{C}$ and $\mathrm{Boc}_{2} \mathrm{O}(0.236 \mathrm{~g}, 1.1 \mathrm{mmol})$ was added. The reaction mixture was stirred for $3 \mathrm{~h}$, extracted once with diethyl ether, acidified with $1 \mathrm{M} \mathrm{HCl}$ to $\mathrm{pH} \mathrm{2-3}$ and extracted again three times with ethyl acetate. The organic layer was dried with sodium sulfate and, after evaporation, the 
product was purified by column chromatography on silica gel [heptane-ethyl acetate-acetic acid (30:30:5)] to give 2 as an oil $(0.215 \mathrm{~g}, 81 \%$ from 1$)[\alpha]_{D}=+13.5(c 1.7$, $\mathrm{MeOH}),\left\{\right.$ lit. $[\alpha]_{\mathrm{D}}=+8.24(c \quad 2.1, \quad \mathrm{MeOH})^{5}$ and $\left.[\alpha]_{\mathrm{D}}=+12.5(c 1.2, \mathrm{MeOH})^{7}\right\} .{ }^{1} \mathrm{H}$ NMR $(270 \mathrm{MHz}$, $\left.\mathrm{CDCl}_{3}\right): \delta 1.42 \quad\left(\mathrm{Boc}-\mathrm{CH}_{3}\right), 3.15$ (d, Ar- $\mathrm{CH}_{2}-\mathrm{P}$, $\left.J_{\mathrm{PCH}}=21.6 \mathrm{~Hz}\right), 3.2\left(\beta-\mathrm{CH}_{2}\right), 3.62,3.66\left(\mathrm{POCH}_{3}\right), 4.59$ $(\alpha-\mathrm{CH}), 5.17(\mathrm{NH}), 7.2(\mathrm{Ar}-\mathrm{H}),{ }^{13} \mathrm{C}$ NMR $(67.9 \mathrm{MHz}$, $\left.\mathrm{CDCl}_{3}\right): \delta 28.3\left(\right.$ Boc- $\left.\mathrm{CH}_{3}\right), 32.1 \quad\left(\mathrm{P}-\mathrm{CH}_{2}-\mathrm{Ar}, \mathrm{d}\right.$, $\left.J_{\mathrm{PC}}=137.5 \mathrm{~Hz}\right), 37.4\left(\beta-\mathrm{CH}_{2}\right), 53.2\left(\mathrm{P}-\mathrm{OCH}_{3}, J_{\mathrm{POC}}=\right.$ $5.5 \mathrm{~Hz}), 54.2(\alpha-\mathrm{CH}), 79.7$ (Boc-C), 129-135 (Ar-C), 155.2 (NHCOO), $173.9 \quad(\mathrm{COOH}) . \quad{ }^{31} \mathrm{P} \quad \mathrm{NMR}$ $\left(109.4 \mathrm{MHz}, \mathrm{CDCl}_{3}\right): \delta+29.8$.

Alkylation of the bis-lactim ether of cyclo(D-Val-Gly) with $\alpha$-bromo- $\alpha^{\prime}$-dimethylphosphono-p-xylene 3. To a solution of the bis-lactim ether of cyclo(D-Val-Gly) (0.406 g, $2.20 \mathrm{mmol})$ in dry $\mathrm{THF}(4 \mathrm{ml})$ at $-78^{\circ} \mathrm{C}$ was added dropwise butyllithium (1.6 $\mathrm{M}$ in hexane; $2.1 \mathrm{ml}$, $3.30 \mathrm{mmol}$ ). After $10 \mathrm{~min}$ a cold solution of $\alpha$-bromo$\alpha^{\prime}$-dimethylphosphono-p-xylene $\mathrm{s}^{5}(0.71 \mathrm{~g}, 2.42 \mathrm{mmol})$ in dry THF $(5 \mathrm{ml})$ was added dropwise. The reaction was allowed to continue at $-78^{\circ} \mathrm{C}$ for $8 \mathrm{~h}$. The reaction was quenched with water and extracted three times with diethyl ether and the combined organic phases were washed with water and dried with sodium sulfate. After evaporation, the crude product was treated with pyridine $(3 \mathrm{ml})$ at $0^{\circ} \mathrm{C}$ for $2 \mathrm{~h}$, to remove the excess of bromo compound, since GC-MS showed that it was difficult to obtain complete alkylation of the anion. Water was added and the mixture was extracted three times with ether. The organic phase was dried with sodium sulfate, evaporated with toluene and purified by column chromatography on silica gel (ethyl acetate) to give 3 as an oil $(0.63 \mathrm{~g}, 72 \%) .{ }^{1} \mathrm{H}$ NMR $\left(270 \mathrm{MHz}, \mathrm{CDCl}_{3}\right): \delta 0.60(\mathrm{~d}, \mathrm{Val} \gamma-\mathrm{H}), 0.94(\mathrm{~d}$, Val $\gamma-\mathrm{H}), 2.12(\mathrm{~m}, \mathrm{Val} \beta-\mathrm{H}), 3.07(\mathrm{Pmp} \beta-\mathrm{H}), 3.12(\mathrm{~d}, \mathrm{Ar}-$ $\left.\mathrm{CH}_{2}-\mathrm{P}, J_{\mathrm{PCH}}=21.6 \mathrm{~Hz}\right), 3.60,3.64\left(\mathrm{OCH}_{3}\right), 3.67,3.71$ $\left(\mathrm{POCH}_{3}\right), 4.3$ (Val $\alpha-\mathrm{H}$ and Pmp $\left.\alpha-\mathrm{H}\right), 7.1$ (Pmp-Ar-H). ${ }^{31} \mathrm{P}$ NMR (109.4 MHz, $\left.\mathrm{CDCl}_{3}\right): \delta+29.0$.

Cleavage of the bis-lactim ether. Compound $3(0.350 \mathrm{~g}$, $0.884 \mathrm{mmol})$ was dissolved in $\mathrm{MeOH}(9 \mathrm{ml})$, and $0.25 \mathrm{M}$ $\mathrm{HCl}(8.7 \mathrm{ml}, 2.18 \mathrm{mmol})$ was added dropwise over $30 \mathrm{~min}$. The reaction mixture was then stirred overnight to yield a mixture of the hydrochlorides of $\mathrm{D}-\mathrm{Val}-\mathrm{OMe}$ and $p$-dimethylphosphonomethyl-L-phenylalanine methyl ester.

Preparation of compound 2. Without separation, the mixture of D-Val-OMe and p-dimethylphosphonomethyl-Lphenylalanine methyl ester was treated with $\mathrm{Boc}_{2} \mathrm{O}$ as above. After extraction and evaporation, the products were separated by column chromatography on silica gel [heptane-ethyl acetate-acetic acid (30:30:5)] to give the methyl ester of 2 as an oil $(0.260 \mathrm{~g}, 73 \%)$.

Hydrolysis of the methyl ester. The methyl ester $(0.260 \mathrm{~g}$, $0.648 \mathrm{mmol}$ ) was hydrolysed with $1 \mathrm{M} \mathrm{NaOH}$ in meth- anol $(0.65 \mathrm{ml})$ for $2 \mathrm{~h}$ at $0^{\circ} \mathrm{C}$. The mixture was acidified with $1 \mathrm{M} \mathrm{HCl}$ and extracted three times with ethyl acetate, dried with sodium sulfate and evaporated. Purification by column chromatography on silica gel [heptaneethyl acetate-acetic acid (30:30:5)] gave 2 as an oil $(0.180 \mathrm{~g}, 72 \%)$.

$[\alpha]_{\mathrm{D}}=+13.1(c 1.8, \mathrm{MeOH})$, lit. $[\alpha]_{\mathrm{D}}=+8.24(c$ 2.1, $\mathrm{MeOH})^{5}$ and $[\alpha]_{\mathrm{D}}=+12.5(c 1.2, \mathrm{MeOH}){ }^{7}{ }^{1} \mathrm{H}$ NMR $\left(270 \mathrm{MHz}, \mathrm{CDCl}_{3}\right): \delta 1.42\left(\mathrm{Boc}-\mathrm{CH}_{3}\right), 3.16(\mathrm{~d}, \mathrm{Ar}-$ $\left.\mathrm{CH}_{2}-\mathrm{P}, \quad J_{\mathrm{PCH}}=21.6 \mathrm{~Hz}\right), \quad 3.2 \quad\left(\beta-\mathrm{CH}_{2}\right), \quad 3.62, \quad 3.66$ $\left(\mathrm{POCH}_{3}\right), 4.56(\alpha-\mathrm{CH}), 5.18(\mathrm{NH}), 7.18(\mathrm{Ar}-\mathrm{H}),{ }^{13} \mathrm{C}$

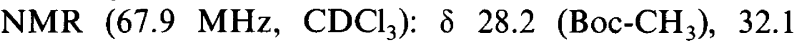
$\left(\mathrm{P}-\mathrm{CH}_{2}-\mathrm{Ar}, \mathrm{d}, J_{\mathrm{P}-\mathrm{C}}=139.3 \mathrm{~Hz}\right), 37.4\left(\beta-\mathrm{CH}_{2}\right), 53.2$ $\left(\mathrm{P}-\mathrm{OCH}_{3}, J_{\mathrm{POC}}=5.5 \mathrm{~Hz}\right), 54.2(\alpha-\mathrm{CH}), 79.6(\mathrm{Boc}-\mathrm{C})$, 129-135 (Ar-C), 155.1 (NHCOO), 174.0 (COOH). ${ }^{31} \mathbf{P}$ NMR (109.4 MHz, $\left.\mathrm{CDCl}_{3}\right): \delta+29.8$.

Synthesis of N-(tert-butoxycarbonyl)-O-(diallylphosphono)L-tyrosine 4. Boc-L-Tyr-OH (500 mg, $1.78 \mathrm{mmol}$ ) and tetrazole $(374 \mathrm{mg}, 5.34 \mathrm{mmol}$ ) were dissolved in dry DCM $(40 \mathrm{ml})$ and the solution was cooled to $0^{\circ} \mathrm{C}$. Diallyl $N, N$ diisopropyl phosphoramidite ${ }^{9}(0.8 \mathrm{ml}, 3.26 \mathrm{mmol})$ was added to the stirred solution. The mixture was stirred for $2 \mathrm{~h}$ at room temperature and then cooled to $-40^{\circ} \mathrm{C}$. A solution of $m$-chloroperbenzoic acid $(676 \mathrm{mg}, 1.96 \mathrm{mmol})$ in DCM $(20 \mathrm{ml})$ was added. The mixture was then stirred $1 \mathrm{~h}$ at $0^{\circ} \mathrm{C}$, extracted with $10 \%$ sodium hydrogen sulfite $(3 \times 50 \mathrm{ml})$, acidified with $1 \mathrm{M} \mathrm{HCl}$ to $\mathrm{pH} 2-3$ and extracted again four times with ethyl acetate. The organic layer was dried with sodium sulfate and, after evaporation, the product was purified by column chromatography on silica gel [heptane-ethyl acetate-acetic acid (30:30:5)] to give 4 as an oil $(0.57 \mathrm{~g}, 73 \%),[\alpha]_{\mathrm{D}}=+43.1$ (c 1.1, $\mathrm{CHCl}_{3}$ ). ${ }^{1} \mathrm{H}$ NMR $\left(270 \mathrm{MHz}, \mathrm{CDCl}_{3}\right): \delta 1.46$ (s, Boc$\left.\mathrm{CH}_{3}\right), 3.17\left(\mathrm{~m}, \beta-\mathrm{CH}_{2}\right), 4.20(\mathrm{~m}, \alpha-\mathrm{CH}), 4.67$ [m, $\left.\left(\mathrm{OCH}_{2} \mathrm{CH}=\mathrm{CH}_{2}\right)_{2}\right], 5.14$ (d, NHCOO), 5.28, 5.32 [dm, $\left.\left(\mathrm{OCH}_{2} \mathrm{CH}=\mathrm{CH}_{2}\right)_{2}\right], 5.95\left[\mathrm{~m},\left(\mathrm{OCH}_{2} \mathrm{CH}=\mathrm{CH}_{2}\right)_{2}\right]$, 7.14 (dd, Ar-H). ${ }^{13} \mathrm{C}$ NMR (67.9 MHz, $\left.\mathrm{CDCl}_{3}\right): \delta 28.4$

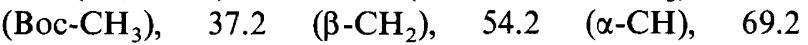
$\left[\left(\mathrm{OCH}_{2} \mathrm{CH}=\mathrm{CH}_{2}\right)_{2}, J_{\mathrm{POC}}=5.5 \mathrm{~Hz}\right], 80.2(\mathrm{Boc}-\mathrm{C}), 119.0$ $\left[\left(\mathrm{OCH}_{2} \mathrm{CH}=\mathrm{CH}_{2}\right)_{2}\right], 120.1\left(\mathrm{ArCH}_{3,5}\right), 130.9\left(\mathrm{ArCH}_{2,6}\right)$ $132.0\left[\left(\mathrm{OCH}_{2} \mathrm{CH}=\mathrm{CH}_{2}\right)_{2}\right], 155.5(\mathrm{NHCOO}), 174.1$ $(\mathrm{COOH}) .{ }^{31} \mathrm{P}$ NMR $\left(109.4 \mathrm{MHz}, \mathrm{CDCl}_{3}\right): \delta-6.3 \mathrm{ppm}$.

Solid-phase synthesis of the $\beta_{1}$ and $\beta_{3}$ integrin chains. The peptides H-K-F-D-T-G-E-N-P-I-Pmp-K-S-A-V-TT-OH $5\left(\beta_{1}\right)$, H-K-F-D-T-A-N-N-P-L-Pmp-K-E-A-T-ST-OH $6\left(\beta_{3}\right)$, H-K-W-D-T-G-E-N-P-I-Y(P)-K-S-A-V-TT-OH $7\left(\beta_{1}\right)$ and H-W-F-D-T-A-N-N-P-L-Y $(P)-\mathrm{K}-\mathrm{E}-\mathrm{A}-$ T-S-T-OH $8\left(\beta_{3}\right)$ were synthesized manually using Merrifield's solid-phase technique ${ }^{10}$ with Boc-protected amino acids. The side-chain functional groups were protected as follows: benzyl for threonine, serine, aspartic acid and glutamic acid, 2-chlorobenzyl for lysine, formyl for tryptophan in peptides $\mathbf{7}$ and $\mathbf{8}$, methyl groups for the phosphonate, and allyl groups for the phosphotriester. In peptide 5, Pmp prepared by the Oppolzer method was used and in the synthesis of peptide 6, Pmp prepared by 
the Schöllkopf method was used. The first Boc-amino acid was covalently linked to a Biorad ${ }^{\circledR}$ chloromethylated polystyrene resin (1.0 equiv. $\mathrm{g}^{-1}$ substitution, $1 \%$ crosslink) according to the KF method ${ }^{11}$ in DMF. Subsequent amino acids were incorporated using a twofold excess of the appropriate $N$-Boc protected amino acids in the presence of two equivalents of DIPCDI and three equivalents of HOBT. The coupling reaction was monitored for completion with a ninhydrin test ${ }^{12}$ and repeated if necessary. The syntheses were performed on a $0.2-$ $0.5 \mathrm{mmol}$ scale in a $100 \mathrm{ml}$ fritted glass-bottomed reaction vessel, using nitrogen for stirring and filtration. ${ }^{13}$

TFMSA cleavage of 5 and $\mathbf{6}$ from resin and removal of all blocking groups. TFMSA $(0.5 \mathrm{ml})$ and TFA $(2.5 \mathrm{ml})$ were mixed and cooled to $0^{\circ} \mathrm{C}$, followed by addition of DMS $(1.5 \mathrm{ml})$ and $m$-cresol $(0.5 \mathrm{ml})$. After stirring for $30 \mathrm{~min}$, the protected peptide-resin ( $0.3 \mathrm{~g}$ for both peptides) was added. The reaction was allowed to take place for $2 \mathrm{~h}$ at $0^{\circ} \mathrm{C}$ and then for an additional $2 \mathrm{~h}$ at room temperature. The peptides were precipitated from the acid with diethyl ether at $-70^{\circ} \mathrm{C}$ and taken up in $10 \%$ aqueous acetic acid. The aqueous phase was evaporated to dryness and the residue desalted on Sephadex ${ }^{\circledR}$ G15 in water and lyophilized to yield the peptides as white fluffy powders $(5,0.238 \mathrm{~g}, 66 \%$ and $6,0.138 \mathrm{~g}, 70 \%)$. The amino acid analyses were satisfactory for both peptides. 5, FAB-MS $(\mathrm{M}+1)^{+} \quad m / z \quad 1848.9$, calc. 1847.9. ${ }^{31} \mathrm{P} \quad \mathrm{NMR}$ $\left(109.4 \mathrm{MHz},{ }^{2} \mathrm{H}_{2} \mathrm{O}\right): \delta+20.6 .6$, FAB-MS $(\mathrm{M}+1)^{+} \mathrm{m} / \mathrm{z}$ 1877.9 calc. 1876.9. ${ }^{31} \mathrm{P}$ NMR $\left(109.4 \mathrm{MHz},{ }^{2} \mathrm{H}_{2} \mathrm{O}\right): \delta$ +20.6 .

Removal of allyl blocking groups from the peptide phosphotriester. Trimethylsilyl azide $(0.42 \mathrm{ml}, 3.2 \mathrm{mmol})$, tetrabutylammonium fluoride $(374 \mathrm{mg}, 1.2 \mathrm{mmol})$ and tetrakis(triphenylphosphine)palladium $(0)(92 \mathrm{mg}, 0.08 \mathrm{mmol})$ were premixed in $6 \mathrm{ml}$ DCM under argon. The mixture was added to the peptide-resin $7(320 \mathrm{mg})$ in DCM under nitrogen. The reaction was allowed to take place with stirring and nitrogen bubbling at room temperature for $30 \mathrm{~min}$. After filtration the resin was washed carefully with DCM and DMF alternately. The peptide-resin 8 was treated in the same way.

TFMSA cleavage of 7 and $\mathbf{8}$ from resin and removal of remaining blocking groups. TFMSA $(0.5 \mathrm{ml})$ and TFA $(2.5 \mathrm{ml})$ were mixed and cooled to $0^{\circ} \mathrm{C}$, followed by addition of DMS $(1.5 \mathrm{ml})$ and $m$-cresol $(0.5 \mathrm{ml})$. After stirring for $30 \mathrm{~min}$ the protected peptide-resin was added. The reaction mixture was stirred for $4 \mathrm{~h}$ at $0^{\circ} \mathrm{C}$. The peptide was precipitated from the acid with diethyl ether at $-70^{\circ} \mathrm{C}$ and taken up in $10 \%$ aqueous acetic acid. The aqueous phase was evaporated to dryness and the residue desalted on Sephadex ${ }^{\circledR}$ G15 in water, lyophilized to yield the peptide as a white fluffy powder. The lyophilized eluate was dissolved in pyridinium acetate buffer and further purified using an FPLC system equipped with a Super$\operatorname{dex}^{\circledR} 30$ column. A check for homogeneity was done by reversed-phase liquid chromatography on a Waters Bondapak C18 $10 \mu \mathrm{m}$ column in a water-acetonitrile $0-100 \%$ gradient in $0.05 \% \mathrm{TFA}$, detection at $214 \mathrm{~nm}$.

The amino acid analyses were satisfactory for both peptides. 7 FAB-MS $(M+1)^{+} m / z$ 1890.0, calc. 1888.9. ${ }^{31} \mathrm{P}$ NMR (109.4 MHz, $\left.{ }^{2} \mathrm{H}_{2} \mathrm{O}\right): \delta$ - 4.04. 8 FAB-MS $(M+1)^{+} \quad m / z \quad 1918.8$ calc. 1917.9. ${ }^{31} \mathrm{P} \quad \mathrm{NMR}$ $\left(109.4 \mathrm{MHz},{ }^{2} \mathrm{H}_{2} \mathrm{O}\right): \delta-4.06$. Both peptides showed in FAB-MS a peak $M+29$ indicating incomplete removal of the formyl group, but ${ }^{1} \mathrm{H}$ NMR spectroscopy indicated that this impurity amounted to less than $5 \%$. Caution must therefore be exercised when using FAB-MS data in assessing the purity of a peptide.

Acknowledgements. This work was supported by grants from the Swedish National Board for Technical Development.

\section{References}

1. Johansson, M. W., Larsson, E., Lüning, B., Pasquale, E. and Ruoslahti, E. J. Cell Biol. 126 (1994) 1299.

2. Marseigne, I. and Roques, B. P. J. Org. Chem. 53 (1988) 3621 .

3. Shoelson, S. E., Chatterjee, S., Chaudhuri, M. and Burke, T. R. Jr. Tetrahedron Lett. 32 (1991) 6061.

4. Schöllkopf, U., Groth, U. and Deng, C. Angew. Chem., Int. Ed. Engl. 20 (1981) 798.

5. Cushman, M. and Lee, E.-S. Tetrahedron Lett. 33 (1992) 1193.

6. Oppolzer, W., Moretti, R. and Thomi, S. Tetrahedron Lett. 30 (1989) 6009.

7. Dow, R. L. and Bechle, B. M. Synlett (1994) 293.

8. Shapiro, G. and Buechler, D. Tetrahedron Lett. 35 (1994) 5421.

9. Bannwarth, W. and Küng, E. Tetrahedron Lett. 30 (1989) 4219.

10. Barany, G. and Merrifield, R. B. In: Gross, E. and Meienhofer, J. Eds., The Peptides, Academic Press, London 1980, Vol. 2, Chap. 1.

11. Clark, J. H. and Miller, J. M. Tetrahedron Lett. 7 (1977) 599.

12. Sarin, V. K., Kent, S. B. H., Tam, J. P. and Merrifield, R. B. Anal. Biochem. 117 (1981) 147.

13. Norberg, T., Lüning, B. and Tejbrant, J. Methods Enzymol. 247 (1994) 87.

Received April 24, 1995. 